\title{
Equilibrium between interest payments and income in the housing market
}

\author{
Paul de Vries $\cdot$ Peter Boelhouwer
}

Received: 30 August 2007/ Accepted: 4 November 2008/Published online: 28 November 2008

(C) The Author(s) 2008. This article is published with open access at Springerlink.com

\begin{abstract}
The literature on housing markets suggests that house prices in almost all western economies can be explained by short-run demand-oriented variables and a longrun term. The basic principles of the theory are that the short-run fluctuations, which are based on recent price developments (shocks), occur due to market imperfection, while over the long term, causality with such fundamentals as income will recover. Nonetheless, many of the interesting questions in housing economics concern adjustments toward equilibrium. This paper seeks to identify a long-run equilibrium between interest payments and household income (interest-to-income ratio) instead of between house prices and income (price-to-income ratio).
\end{abstract}

Keywords House prices - Interest payments - Error-correction model · Housing market equilibrium · Household income $\cdot$ The Netherlands

\section{Introduction}

House prices have been studied extensively and with a variety of methods. Evidence indicates that both short-run fundamentals and long-run fundamentals have an impact on houses prices. In the short term, significant upward or downward movements ('shocks') appear, due to speculative or psychological effects (for example, see Reichert 1990; Levin and Wright 1997; Meen 1998; Hort 1998; De Vries and Boelhouwer 2005). For example, when prices continue to increase, consumers tend to act swiftly in anticipation of further increases. Recent price developments have been used to compile models of such short-run price fluctuations (Abraham and Hendershott 1996; Hort 1998; Malpezzi 1999). The term 'bubble builder' is often used in this context.

In addition to short-run price effects, other more permanent factors play a role in the development of house prices. Many analytical models include income and inflation as

P. de Vries $(\bowtie) \cdot$ P. Boelhouwer

OTB Research Institute for Housing, Urban and Mobility Studies, Department of Housing Policy and Housing Market, Delft University of Technology, P.O. Box 5030, 2600 GA Delft, The Netherlands e-mail: p.devries@tudelft.nl 
explanatory variables for price trends (see Reichert 1990; Peng and Wheaton 1994; Cho 1996; Gallin 2003; Boelhouwer and De Vries 2002; De Vries 2002; Malpezzi 1999; Hort 2000; Meen 2002). To ensure that long-run price developments can also be explained by permanent factors, such models incorporate a deviation from equilibrium as a corrective variable (error-correction models). The long-run equilibrium is usually expressed as a price-to-income ratio. As early as 1972, Fair drew attention to the significance of the longrun equilibrium between house prices and incomes. This equilibrium, as he states, stems directly from the premises of general price theory, which proposes that the demand for an object is a function of income and the price of the object or service in relation to other prices (Fair 1972).

This idea is commonly formalized in the housing literature by positing a co-integration relationship between house prices and fundamentals (e.g., income) with subsequent estimation of an error-correction model (Abraham and Hendershott 1996; Malpezzi 1999; Hort 1998; Meen 2002; Boelhouwer et al. 2004). Gallin (2003) of the Federal Reserve Board suggests, however, that the co-integration relationship between income and house prices that is commonly found in the literature may be inappropriate. He shows that extensive panel data tests in the United States have found no evidence of co-integration. 'This does not mean that fundamentals do not affect house prices, but it does mean that the level of house prices does not appear to be tied to the level of fundamentals.' Gallin questions the validity of the associated error-correction models, which are based on long-run equilibrium in the price-to-income ratio. However, according Holly and Yamagata (2006), the bootstrap panel unit root tests reported by Gallin can be subject to large size distortions. After additional research, they conclude that the $\log$ of real house prices and the log of real disposable income are co-integrated. On the other hand, Chen et al. (2007) found no co-integration relationship from the empirical results of Taiwan's data.

This paper presents a long-run equilibrium between interest payments and income (interest-to-income ratio) over the error-correction term. It is thought that interest payments are linked to income levels by a stable long-run relationship. Although they may drift apart temporarily, they tend to return to a long-run equilibrium. The equilibrium path may also shift over time. This process forms the basis for an error-correction model that may serve to explain and predict fluctuations in house prices. The model takes account of the ability of low nominal interest rates in recent years to support higher than average price-to-income ratios.

Especially in the Dutch context, modeling the house price development including the interest-to-income ratio instead of the price-to-income ratio has grounds. For instance, OECD mentions that house prices do not appear to be linked to income by stable long-run relationships, possibly because the cost of carrying a mortgage varies over time (OECD 2005). Furthermore, Dutch households have strong incentives to maintain mortgages at high levels given the favorable tax treatment of debt-financed owner-occupied housing (Ter Rele and van Steen 2001). Van Rooij (2002) concludes that recent house buyers in The Netherlands face the highest loan-to-value ratio of more than $75 \%$, with a mean ratio of $92 \%$ for the most recent buyers. Despite the stimulation of market forces after 1990, we mention the absence of an adequate supply reaction to the steep rise in house prices, the scarcity of newly built dwellings and the policy of the financial institutions imposing more or less the maximum house price by adopted ceilings for the interest-to-income ratio.

The following section provides a brief description of the serial correlation in house prices as one of the main causes of the short-run shocks, which serve to overshadow and obscure the equilibrium between prices (or interest payments) and income. We then proceed to consider the long-run relationship between house prices and income 
(price-to-income ratio) in greater depth, presenting an alternative in the form of the interest-to-income ratio, as a basis for the error-correction term in the main section of this paper (Sect. 4). The conclusions are presented in Sect. 5.

\section{House-price models and short-run shocks}

House-price development can be explained according to a neo-classical theoretical formulation. Demand and supply in the housing market and the resulting equilibrium price are central components of this theory. Demand for housing is a function of factors such as demography, income, interest payments, user cost and availability of substitutes. Supply for housing in the short run is inelastic, but in the long run, supply is a function of the factors influencing building constructors to construct new houses. Therefore, it can be assumed that, in the long run, house-price development will be determined by production costs in a competitive housing market. When prices rise in response to (temporary) scarcity, building contractors react to this favorable situation by adding attractively priced, newly built housing to the stock. This extra supply of new housing depresses prices, creating a new equilibrium on the housing market. This proposition implicitly assumes that the housing market operates as a supply market. House prices function as a trigger, inducing movement towards equality between housing supply and demand. The idea behind this supply-directed approach is that, in the long run, price follows the production costs. The factors that determine the costs of new construction (including both land and construction costs) mark the starting point for a new price equilibrium.

When a lack of building opportunities renders the supply of newly built housing incapable of adequately anticipating the changed housing demand, house prices will be formulated primarily within the existing housing stock. This applies particularly to countries (such as The Netherlands) in which the housing and house-building market are strongly regulated and in which building land is scarce. The housing market is an inefficient market (Case and Shiller 1989). The international housing market literature also emphasizes how little influence supply (e.g., new construction) may have on price development in the existing stock. The development of aggregated house prices is thus heavily influenced by household income, mortgage interest rates and the lag in house prices (Abraham and Hendershott 1996; Hort 1998; Malpezzi 1999).

With regard to dynamics, the price equation exhibits short-run positive autocorrelation with some evidence of longer-term mean reversion. This is a widely observed feature of univariate house-price models (see Englund and Ioannides 1997 for an international comparison). Many models therefore use lagged house price as an explanatory variable, thereby constantly accounting for significant short-run price movements. This effect is modeled in the context of the USA in studies by Abraham and Hendershott (1996) and Malpezzi (1999). Hort (1998) applies the model to the Swedish context, using the term 'speculative' price movements.

Various articles have sought to analyze these (short-run) speculative price movements and the associated market inefficiency (Boelhouwer et al. 2004; Hort 1998). In combination with the slow adaptation process of the new-build market, these effects serve to explain the short-run price movements, which are sometimes extremely significant. When prices are perceived to be rising, consumers wish to act swiftly. The sooner the decision to buy is made in such an expanding market, the greater will be the capital gain. The opposite effect can be observed when prices are falling; consumers tend to delay the purchase 
decision for as long as possible in an attempt to preclude equity losses. Short-run shocks are an indicator of inefficient markets.

The literature is replete with evidence of housing-market inefficiency (Cho 1996). One of the main indicators is the fact that house-price movements correlate with historical price levels. Such a relationship would be impossible in an optimally functioning market. This basic function is designated as Eq. 1:

$$
\left(\mathrm{P}_{\mathrm{t}}\right)=\beta_{0}+\beta_{1}\left(\mathrm{P}_{\mathrm{t}-1}\right)+\varepsilon_{\mathrm{t}}
$$

where $\mathrm{P}_{\mathrm{t}}$ is percentage of change real (lagged) house price, and $\varepsilon_{\mathrm{t}}$ is error term.

This autoregressive model tests whether the coefficient $\left(\beta_{1}\right)$ of the lagged house price $\left(\mathrm{P}_{\mathrm{t}-1}\right)$ is zero, in order to demonstrate market efficiency, given that historical price movement, $\mathrm{P}_{\mathrm{t}-1}$, has (or should have) no effect on current price movement, $\mathrm{P}_{\mathrm{t}}$. As many studies have shown, however, there is indeed a situation in which $\beta_{1} \neq 0$, thus demonstrating serial correlation (Case and Shiller 1990; Hort 2000; Berg 2002; Meen 2002). The term 'bubble builder' was coined in this context and means that the housing market is a market in which prices are never stable, but are always shifting in the direction of long-run equilibrium. Lagged house-price change is obviously not the only determinant of price changes. Adding the other variables to the autoregressive model results in an autoregressive distributed lag model.

\section{Towards long-run equilibrium}

The results of house-price models are dominated by short-run effects, in which the market is never in perfect balance. Recurrent short-run shocks (serial correlation) ensure that prices continue to shift one way or the other. This impedes the likelihood of achieving long-run equilibrium among house price and such fundamentals as income, interest rate, population growth, or user costs. This suggests that a couple of variables disrupt the equilibrium.

Hendry (1984), Drake (1993) and Abraham and Hendershott (1996) were among the first to use model analyses to investigate long-run relationships. Especially Abraham and Hendershott proposed two models, one of which was based on equilibrium price and the other on deviations from that price. As shown in Fig. 1, the first model results in a straight line (the long-run equilibrium) and the second in the difference between this line and the wavy short-run price development (short-run shocks). Abraham and Hendershott estimate equilibrium price as a function of construction costs, income, the unemployment rate and changes in the net interest-rate payments (corrected for tax deductibility). They then set these estimated equilibrium prices against the actual house prices in each period, using the difference as a measure of the imbalance that provides insight into the adaptation process. Finally, they formulated a function for this adaptation process.

\subsection{Price-to-income ratio}

Recent models incorporate a variable that represents the balance between house price and income. Specifically, this variable seeks to bring house price back towards equilibrium. Long-run equilibrium can be seen as an error-correction mechanism. This notion is formalized in the housing literature by positing a co-integration relationship between house price and income. Prices and income are thus linked by a stable long-run relationship: they 
Fig. 1 The long-run relationship between house price and income and the short-run shocks on the housing market. Source: De Vries and Boelhouwer (2003)

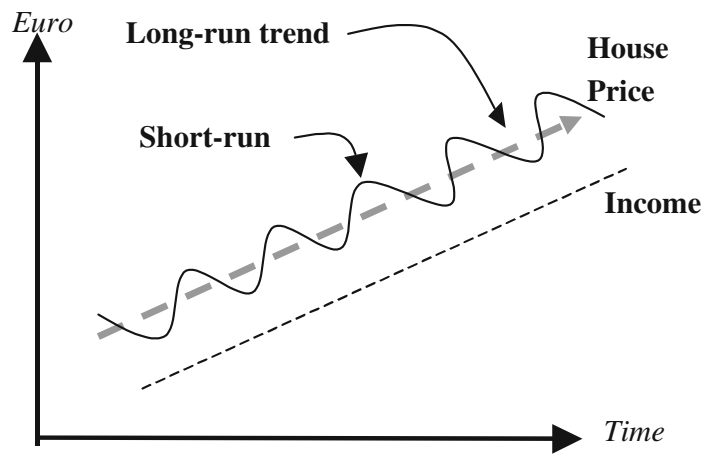

may drift apart temporarily, but they tend to return to their long-run equilibrium. Models based on this approach have been applied in the UK, Finland, Sweden and The Netherlands. In the US, the literature has also placed a marked emphasis on the aggregated ratio between house price and income (Case and Shiller 1990; Abraham and Hendershott 1996; Malpezzi 1999; Meen 2002).

However, these findings are not established by all researchers. Gallin (2003), for instance, finds no evidence for co-integration. He suggests that the error-correction specification for house price and income based on the price-to-income ratio may be inappropriate.

\subsection{Net interest payments}

We assume a long-run equilibrium between net interest payments (rather than house price) and income (Boelhouwer and De Vries 2002). The Dutch Central Bank (Van Rooij 2002) concludes that especially recently moved house buyers faced very high loan-to-value ratios, indicating that the maximum borrowing capacity based on household income leads to the final house price. To obtain an impression of the development of the financing space of a household, the maximum obtainable mortgage is depicted for three income groups at five points in time (Fig. 2). Here we have made use of the Woningbehoeftenonderzoek (WBO) (Housing Demand Survey WBO) commissioned by the Dutch government and carried out every 4 years. The maximal obtainable mortgage takes the rules applied by mortgage brokers and banks into account, as well as interest rates and income. Borrowing limits, which had come under severe pressure during the previous period, rose over the 1982-1986 period. Prices, which were also emerging from a deep dip, did not immediately respond to the increase in opportunity, presumably because most households were still mindful of the severe recession. During the next period, the difference disappeared again, then in the 1990s prices and borrowing limits kept reasonably in step. Another interesting point is that the gap between borrowing limits and prices has gradually narrowed.

Figure 3 demonstrates that, in The Netherlands, there is indeed a simple long-run relationship between net interest payments $\left(\mathrm{NIP}_{t}\right)$ and household income $\left(\mathrm{I}_{t}\right)$. In respect to the long term, it may be seen that both factors follow a parallel development, especially in the 1990s. Because net interest payments are the product of three factors - house price, mortgage interest rates and fiscal arrangements (deductibility) - a direct correlation with house price may be drawn. The philosophy of the long-run relationship is that there are periods that indicate the strength and direction of a linear relationship and that there are periods out of equilibrium. 


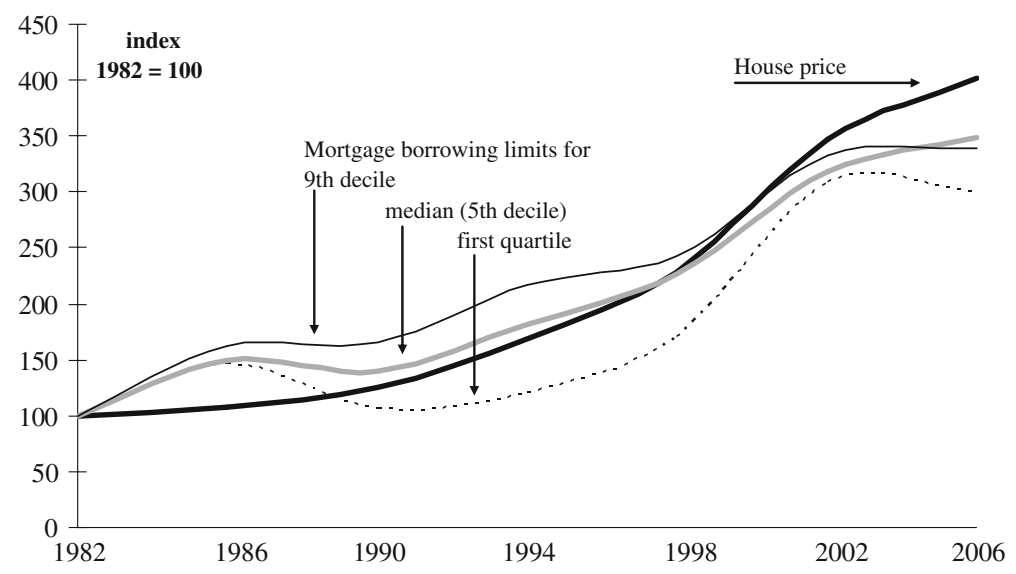

Fig. 2 Mortgage borrowing limits for households with a perceived household income of 25, 50 and $90 \%$ of income distribution and prices in the existing housing stock during the 1982-2006 period (index 1982 = 100). Source: OTB computations based on data from various housing surveys, mortgage brokers, the National Mortgage Guarantee Scheme and the Dutch Association of Real Estate Brokers and Real Estate Experts (NVM)

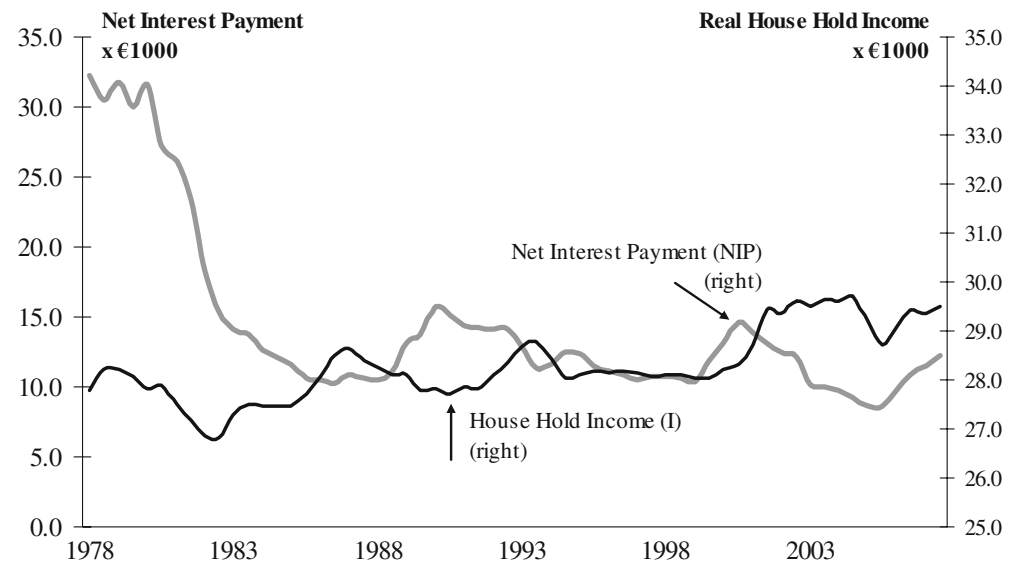

Fig. 3 Development of real household income and net interest payments (euro 2000), half-year periods, 1978 - first half year 2008. Source: CBS (Statistics Netherlands), adapted by OTB TUDelft

Equations 2 and 3 show how net interest payments $\left(\mathrm{NIP}_{\mathrm{t}}\right)$ and interest-to-income ratio $\left(\mathrm{IIR}_{\mathrm{t}}\right)$ are calculated. The net interest payments must be calculated first (Eq. 2).

$$
\mathrm{NIP}_{\mathrm{t}}=\mathrm{P}_{\mathrm{t}} * \mathrm{IR}_{\mathrm{t}} *(1-\mathrm{F})
$$

where NIP is net interest payment (at time of purchase), $\mathrm{P}$ is house price, IR is interest rate, and $\mathrm{F}$ is fiscal advantage (0.405).

According to this function, the net interest payments $\left(\mathrm{NIP}_{t}\right)$ at the time of purchase will depend on the current house price $\left(\mathrm{P}_{t}\right)$, the current mortgage interest rate $\left(\mathrm{IR}_{\mathrm{t}}\right)$ and a non-time-dependent fiscal benefit in the form of tax deductibility. Because fiscal 
arrangements for owner-occupiers in The Netherlands have remained largely unchanged over the past decade, the fiscal benefit $(\mathrm{F})$ can be applied over the entire period. Owners are responsible for $59.5 \%$ of the interest liability; the remaining $40.5 \%$ is paid by the government (Boelhouwer et al. 2004). The fiscal advantage is therefore a constant $(40.5 \%)$.

The net interest payments $\left(\mathrm{NIP}_{\mathrm{t}}\right)$ can then be used to establish the interest-to-income ratio $\left(\mathrm{IIR}_{\mathrm{t}}\right)$ (Eq. 3); the result forms the basis for the long-run equilibrium in the final model.

$$
\mathrm{IIR}_{\mathrm{t}}=\mathrm{NIP}_{\mathrm{t}} / \mathrm{I}_{\mathrm{t}}
$$

where IIR is interest-to-income ratio (at time of purchase), NIP is net interest payments (mortgage debt only), and I is household income (per household).

We deliberately chose the interest-to-income ratio $\left(\mathrm{IIR}_{\mathrm{t}}\right)$ over the price-to-income ratio as our error-correction term. The price-to-income ratio is influenced by a variety of factors that cannot be expressed or explained in simple terms (see Gallin 2003).

The Dutch housing market at the end of the 1990s showed a rapid rise in prices against a relatively stable interest-to-income ratio (see also Fig. 4). In practice, supply has not responded to the steep rise in house prices. Intuitively, production and price should be in equilibrium in the long run; however, this notion has not been adequately proven in research. Goodman (1998), DiPasquale and Wheaton (1994) indicate that, as a rule, the relationship between house price and new housing supply leads to weak analyses on an aggregate level. In The Netherlands, the influence exerted by housing supply was also not significant. Only the large numbers of newly built housing in the areas surrounding the major Dutch cities have had any influence on the development of (regional) house prices (De Vries and Boelhouwer 2005). On the aggregate level, the price increase was primarily the result of a decrease in mortgage rates and an increase in average incomes. Our hypothesis is that the Dutch housing consumer assesses the price of a house in terms of the affordability of the payments. Accordingly, the interest-to-income ratio (IIR) can usefully serve as the error-correction term.

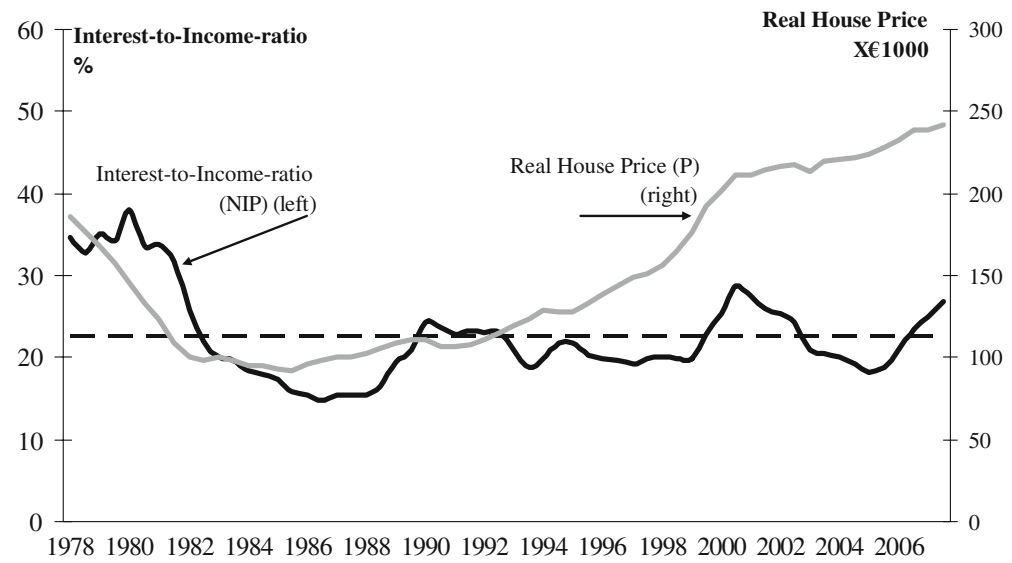

Fig. 4 Interest-to-income ratio, real house price (euro 2000) and the constant long-run equilibrium, halfyear periods, 1978 - first half year 2008. Source: NVM (Dutch Association of Brokers)/CBS (Statistics Netherlands)/House-price model OTB TUDelft, adapted by OTB TUDelft 


\section{Modeling the long-run equilibrium}

One basic assumption of these models is that, although the interest-to-income ratio (IIR $\mathrm{t}_{\mathrm{t}}$ may drift up and down, they will tend to return to a constant long-run equilibrium. ${ }^{1}$ Using a stochastic model, Malpezzi (1999) was able to propose a constant long-run equilibrium based on the price-to-income ratio by using averages for periods in which a significant degree of market equilibrium could be observed. Finally, the deviation between the observed price-to-income ratio and the constant long-run equilibrium could be incorporated into a house price model.

Such analyses require large historical data resources, while our model is estimated for the period from the first half of 1978 through the first half of 2008 (61 6-monthly observations). In order to be able to apply the principle of the error-correction model anyway, we estimated the long-run equilibrium (LRE) simultaneously with our autoregressive distributed lag model (for a detailed explanation, see Boelhouwer et al. 2004). The basic idea is that the LRE can be determined by dividing the regression coefficient of the constant term by the regression coefficient of the interest-to-income ratio $\left(\mathrm{IIR}_{\mathrm{t}}\right)$.

First, the model (Eq. 4) is formulated to include the interest-to-income ratio (IIR $)$ and a constant term. In addition to the interest-to-income ratio, the model takes into account a number of other economic and housing market effects: the percentage of change in real house prices $\left(\mathrm{P}_{\mathrm{t}}\right)$, which is a function of the lagged dependent variable $\left(\mathrm{P}_{t-1}\right)$, the change in real interest rate $\left(\mathrm{IR}_{\mathrm{t}}\right)$ and the change in real household income $\left(\mathrm{I}_{\mathrm{t}}\right)$. The statistically significant $t$-value is shown in brackets below:

$$
\begin{array}{r}
\mathrm{P}_{\mathrm{t}}=5.41+0.50 \mathrm{P}_{\mathrm{t}-1}-0.23 \mathrm{IIR}_{\mathrm{t}-1}-1.50 \mathrm{IR}_{\mathrm{t}}+0.64 \mathrm{I}_{\mathrm{t}} \\
(+3.74)(+5.38)(-3.86)(-2.09)(+1.88)
\end{array}
$$

Of course, it is well known that other price measures are available (e.g., housing supply, building costs and demographic characteristics). In the Dutch context, however, the influence exerted by these variables on the variation in house prices was either absent or statistically insignificant. Altogether, this had no influence on the explanatory power of the model; the $R^{2}$ of 0.70 is good. Also, the tests for autocorrelation (the presence of autocorrelation in price changes could lead to a misspecified model) yield good results (Durbin Watson of 2.14).

Secondly, the long-run equilibrium can then be determined by dividing the regression coefficient of the constant term (5.41) by the regression coefficient of the interest-toincome ratio (0.23). According to this calculation, the long-run equilibrium (LRE) is 23.2 (see also Fig. 4). In other words, the interest payment liability in each period is $23.2 \%$ of income. This ratio is seen as a good and reliable estimate. The Housing Demand Survey (WBO), which was commissioned every 4 years by the government and which contains information from more than 50,000 households, provided for the owner-occupied sector quotes of 22.9, 25.5, 24.5 and 25.0 for respectively 1994, 1998, 2002 and 2006.

Finally, the difference between the actual (known) ratio $\left(\mathrm{IIR}_{\mathrm{t}}\right)$ and this constant equilibrium (LRE) is calculated as follows (Eq. 5):

\footnotetext{
1 In The Netherlands, the constant character of long-run equilibrium raises a number of questions. A followup study formulated a model in which the long-run equilibrium was given a more dynamic character (De Vries and Boelhouwer 2004). The basic idea of the model is that the interest-to-income ratio is never in true equilibrium, but it will also never deviate enormously from the mean, as households would then experience severe financial difficulty in meeting interest payments. However, the output of models with a non-fixed interest-to-income ratio does not differ greatly from a model that applies a constant ratio.
} 


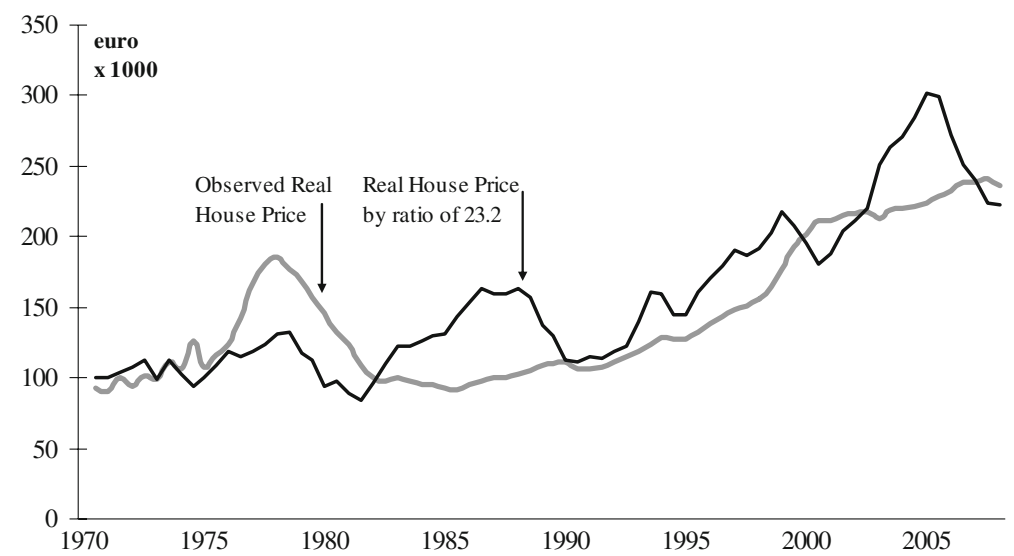

Fig. 5 Actual real house price and the projected real house price in equilibrium, half-year periods, 1978 first half year 2008. Source: House-price model OTB TUDelft

$$
\mathrm{DLRE}_{\mathrm{t}}=\mathrm{IIR}_{\mathrm{t}}-\mathrm{LRE}
$$

where DLRE is deviation from long-run equilibrium, IIR is interest-to-income ratio, and LRE is long-run equilibrium (23.2).

Notice that if the interest-to-income ratio $\left(\mathrm{IIR}_{\mathrm{t}}\right)$ is higher than the market long-run equilibrium (LRE), prices will tend to fall. Conversely, prices tend to rise when $\mathrm{IIR}_{\mathrm{t}}$ is lower than LRE. Alternatively, for Eq. 4 we can estimate an error-correction model, incorporating the deviation from the long-run equilibrium (DLRE) instead of the interestto-income ratio $\left(\mathrm{IIR}_{\mathrm{t}}\right)$ with no constant.

Using Eqs. 2 and 3, we calculate the real house price in a situation in which the interestto-income-ratio is in equilibrium $(23.2 \%$ in each period). Figure 5 presents the actual development of real house price and projected equilibrium house price. We see that house prices have been out of equilibrium for some time - as in the situation that was predicted by the theory. Lower interest rates and higher incomes have, to some extent, compensated for the significant price increases of the 1990s; the interest-to-income ratio has thus remained reasonably stable, or has even developed at a rate below that of the equilibrium line. Because interest payment liabilities began to rise somewhat more rapidly in 2000 , an imbalance begins to emerge in that year. In order to achieve long-run equilibrium, house prices therefore begin to adjust downward gradually.

\section{Conclusion}

Many housing market researchers seek to shed light on short-run and long-run relationships between house prices and income. The basic principles of the theory are that short-run fluctuations ('shocks') occur due to market imperfection, while over the long term, causality with such fundamentals as income or population growth will recover. One of the strongest indicators of these short-run shocks is the evidence that pricing on the current housing market correlates with prices in the past. Were the market functioning optimally, this relationship could not exist. In the practice of house-price modeling, this serial 
correlation is corrected by a variable that establishes long-run equilibrium between house price and income (price-to-income ratio). Although market imperfection may render this ratio artificially high or artificially low during certain periods, market corrections eventually take effect, restoring the overall equilibrium between house price and income. This long-run equilibrium has been applied in many price models. The use of the relationship as (part of) an error-correction mechanism, however, is not without criticism.

With regard to the situation in The Netherlands, we have assumed a long-run relationship between net interest payments and income, whereby affordability becomes the key factor in long-run equilibrium. Boelhouwer and De Vries (2002) arrived at a long-run equilibrium ratio of 23.2. The output of the model, including the interest-to-income ratio instead of the price-to-income ratio, gives a good statistical result.

The presented model could also be used for more policy-orientated purposes. An example of this application is a calculation of the effects of the abolishing of the deduction of the mortgage tax relief interest from taxable income. In contrast with almost all West European countries, the Dutch government did not change this policy during the last decades. However, many analysts and institutions have called this generous subsidizing of home ownership into question when considering the need to create a more stable market situation. Such respectable institutions as the Dutch Central Bank and the VROM council, the Dutch Council for Housing, Spatial Planning and the Environment have in the last few years advocated restraint of the fiscal subsidizing for home ownership. In addition to the objections of political parties who foresee serious problems being raised by their electoral supporters, many opponents to such a radical change draw attention to the possible negative consequences of the curtailment of mortgage interest deduction. They expect a dramatic fall of house prices as a result of such a policy. To get an indication of this effect, the house price model could be used in the following way. Equation 4 includes a parameter for the fiscal benefit (F). Because fiscal arrangements for owner-occupiers have remained largely unchanged over the past decade, fiscal benefit, F, is a constant factor in the model (Eq. 2). However, changes in the fiscal system could affect movements in house prices in The Netherlands. Using the house price model, in 2007, we estimated the effect of abolishing or curtailing the deduction (De Vries 2007) by taking a fiscal policy variant that operates by a way of housing costs and translated it into an interest supplement. In other words, the retraction of the fiscal advantages of home ownership translates into a (constant) higher rate of interest because of the higher housing costs incurred. According to the model calculations, Dutch house prices will decline over the next years by a maximum of $32 \%$.

Open Access This article is distributed under the terms of the Creative Commons Attribution Noncommercial License which permits any noncommercial use, distribution, and reproduction in any medium, provided the original author(s) and source are credited.

\section{References}

Abraham, J. M., \& Hendershott, P. H. (1996). Bubbles in metropolitan housing markets. Journal of Housing Research, 7(2), 191-207.

Berg, L. (2002). Prices on the second-hand market for Swedish family houses: Correlation, causation and determinants. European Journal of Housing Policy, 2, 1-24.

Boelhouwer, P. J., \& De Vries, P. (2002). Housing production in the Netherlands: A growing misbalance between state and market. Paper for ENHR 2002 conference "Housing Cultures-Convergence and Diversity in Vienna", 1-5 July 2002.

Boelhouwer, P. J., Haffner, M. E. A., Neuteboom, P., \& De Vries, P. (2004). House prices and income tax in the Netherlands: An international perspective. Housing Studies, 19, 414-432. 
Case, K. E., \& Shiller, R. J. (1989). The efficiency of the market for single-family homes. The American Economic Review, 79(1), 125-137.

Case, K. E., \& Shiller, R. J. (1990). Forecasting prices and excess returns in the housing market. AREUEA Journal, 18, 253-273.

Chen, M. C., Tsai, I. C., \& Chang, C. O. (2007). House prices and household income: Do they move apart? Evidence from Taiwan. Habitat International, 31, 243-256.

Cho, M. (1996). House price dynamics: A survey of theoretical and empirical issues. Journal of Housing Research, 7(2), 145-172.

De Vries, P. (2002). House price dynamics (De Dynamiek in de verkoopprijs van woningen). Ruimte and Planning, 12, 360-363.

De Vries, P., \& Boelhouwer, P. J. (2003). Local house price development and new housing supply. Paper presented at the ERES Conference, Helsinki.

De Vries, P., \& Boelhouwer, P. J. (2004). Long-run equilibrium at the owners occupied housing marktet (Lange termijnevenwicht op de koopwoningmarkt), DGVH/NETHUR Partnership. Utrecht: Nethur.

De Vries, P., \& Boelhouwer, P. J. (2005). Local house price developments and housing supply. Property Management, 23(2), 80-96.

De Vries, P. (2007). Effects on house price by deduction mortgage interest (Koopprijseffecten door afbouw hypotheekrenteaftrek, de lineaire variant). Delft: Research Institute OTB TUDelft.

DiPasquale, D., \& Wheaton, W. C. (1994). Housing market dynamics and the future of housing prices. Journal of Urban Economics, 35, 1-27.

Drake, L. (1993). Modelling UK house prices using cointegration: An application of the Johansen technique. Applied Economics, 25, 1225-1228.

Englund, P., \& Ioannides, Y. M. (1997). House price dynamics: An international empirical perspective. Journal of Housing Economics, 6, 119-136.

Fair, R. C. (1972). Disequilibrium in housing models. Journal of Finance, 27, 207-221.

Gallin, J. (2003). The long-run relationship between house prices and income: Evidence from local housing markets, Board of Governors of the Federal Reserve System (U.S.). In its series Finance and Economics Discussion Series with number 2003-17.

Goodman, J. R., Jr. (1998). Aggregation of local housing markets. Journal of Real Estate Finance and Economics, 16(1), 93-120.

Hendry, D. F. (1984). Econometric modelling of house prices in the UK. In D. F. Hendry \& K. F. Wallis (Eds.), Econometrics and quantitative economics. Oxford: Basil Blackwell.

Holly, S., Pesaran M. H., \& Yamagata, T. (2006). A spatio-temporal model of house prices in the US, IZA / discussion Paper No. 2338. Bonn, Germany.

Hort, K. (1998). The determinants of urban house price fluctuations in Sweden 1968-1994. Journal of Housing Economics, 7, 93-120.

Hort, K. (2000). Prices and turnover in de market for owner-occupied homes. Regional Science and Urban Economics, 30, 99-119.

Levin, E. J., \& Wright, R. E. (1997). Speculation in the housing market. Urban Studies, 34(9), 1419-1437.

Malpezzi, S. (1999). A simple error correction model of house prices. Journal of Housing Economics, 13, 27-62.

Meen, G. (1998). 25 Years of house price modelling in the UK. What have we learnt and where do we go from here? Paper presented at the ENHR Conference in Cardiff, September 7.

Meen, G. (2002). The time-series behavior of house prices: A transatlantic divide? Journal of Housing Economics, 11, 1-23.

OECD. (2005). Recent house price developments: the role of fundamentals. OECD Economic Outlook, 78, $123-154$.

Peng, R., \& Wheaton, W. C. (1994). Effects of restrictive land supply on housing in Hong Kong: An econometric analysis. Journal of Housing Research, 5(2), 263-291.

Reichert, A. K. (1990). The impact of interest rates, income and employment upon regional house prices. Journal of Real Estate Finance and Economics, 3(4), 373-391.

Ter Rele, H., \& Van Steen, G. (2001). Housing subsidisation in the Netherlands: Measuring its distortionary and distributional effects. CPB Discussion Paper, 2, The Hague, The Netherlands.

Van Rooij, M. C. J. (2002). Financial vulnerability of mortgage owners and mortgage lenders. Dutch Central Bank, Research report 706, Amsterdam, The Netherlands. 